\title{
KEMAMPUAN REPRESENTASI MATEMATIS SISWA DITINJAU DARI LEVEL TEORI BELAJAR VAN HIELE PADA MATERI SEGIEMPAT
}

\author{
Windah Maria Mutiara Tamba ${ }^{1}$, Ribka Kariani Sembiring ${ }^{2}$, \\ Sinta Dameria Simanjuntak ${ }^{3}$ \\ Pendidikan Matematika, Universitas Katolik Santo Thomas 1,2,3 \\ windahmaria457@gmail.com ${ }^{1}$
}

\begin{abstract}
ABSTRAK
Penelitian ini merupakan penelitian deskriptif kualitatif yang bertujuan untuk mengidentifikasi atau mendeskripsikan kemampuan representasi matematis siswa berdasarkan level teori Van Hiele pada materi segiempat. Penelitian ini dilaksanakan pada bulan Mei 2021. Subjek dalam penelitian ini adalah empat orang siswa kelas VII SMP RK Deli Murni Bandar Baru yang merupakan perwakilan dari tiap level teori Van Hiele dengan cara memberikan soal VHGT (Van Hiele Geometry Test). Subjek penelitian diberi tes kemampuan representasi matematis dan kemudian diwawancara. Data dianalisis secara deskriptif kualitatif. Berdasarkan hasil analisis didapatkan bahwa kemampuan representasi matematis siswa dengan tingkat berpikir previsualisasi (level pra 0) memiliki kemampuan representasi visual, namun memiliki kemampuan representasi simbolik dan kemampuan representasi verbal yang masih lemah dan berada pada kategori kurang. Siswa dengan tingkat berpikir visualisasi (level 0) memiliki kemampuan representasi visual, memiliki kemampuan representasi verbal yang masih lemah dan tidak memiliki kemampuan representasi simbolik dan berada pada kategori kurang. Siswa dengan tingkat berpikir analisis (level 1) memiliki kemampuan representasi visual dan kemampuan representasi simbolik, namun memiliki kemampuan representasi verbal yang masih lemah dan berada pada kategori tinggi. Siswa dengan tingkat berpikir deduksi informal (level 2) memiliki kemampuan representasi visual, kemampuan representasi simbolik dan kemampuan representasi verbal dan berada pada kategori sangat tinggi.
\end{abstract}

Kata kunci : kemampuan representasi matematis, segiempat, Van Hiele

\begin{abstract}
This study is a qualitative descriptive study that aims to investigate or describe students' mathematical representation abilities based on their understanding of Van Hiele's theory on quadrilateral material. This study was carried out in May 2021. Four grade VII students from SMP RK Deli Murni Bandar Baru participated in this study as representatives of each level of Van Hiele's theory by answering VHGT (Van Hiele Geometry Test) questions. Subjects were given a mathematical representation ability test before being interviewed. The data was analyzed descriptively and qualitatively. According to the findings of the analysis, students with previsualization thinking level (pre 0) had visual representation abilities, but had symbolic representation abilities and verbal representation skills that were still weak and in the poor category. Students with a visualization thinking level (level 0) have poor visual representation skills, poor verbal representation skills, and no symbolic representation skills. Students
\end{abstract}


with an analytical thinking level (level 1) have strong visual and symbolic representation skills but poor verbal representation skills, placing them in the high category. Students with a level of informal deductive thinking (level 2) have very high visual representation skills, symbolic representation abilities, and verbal representation abilities.

Keywords : mathematical representation ability, quadriterial, Van Hiele

\section{PENDAHULUAN}

Kemampuan representasi matematis merupakan salah satu bagian dari kemampuan matematika. Kemampuan representasi matematis merupakan ungkapanungkapan dari ide-ide matematis untuk mencari solusi dari permasalahan yang ada. Kemampuan representasi matematis juga dapat membantu siswa dalam mengembangkan kemampuan yang dimilikinya untuk memecahkan suatu masalah.

Pentingnya kemampuan representasi matematis diungkapkan oleh Wahyudin (Sapitri dan Ramlah, 2019:830), kemampuan representasi sangat diperlukan untuk membantu para siswa dalam mengatur pemikirannya. Dengan kata lain, apabila siswa memiliki kemampuan merepresentasikan gagasan mereka, artinya mereka lebih memperluas kapasitas untuk berpikir secara matematis. Namun pada kenyataannya peserta didik merasa kesulitan jika dihadapkan dengan kemampuan representasi matematis, peserta didik merasa bingung ketika diminta dalam mempresentasikan arti atau makna ke dalam bentuk simbol maupun bentuk matematika. Triono (2017:67) menyebutkan dalam penelitiannya bahwa kesalahankesalahan siswa dalam merepresentasikan disebabkan oleh rendahnya kemampuan siswa dalam merepresentasikan permasalahan yang diberikan. Siswa menunjukkan ketidakpahaman dalam menggunakan simbol-simbol matematika.

Untuk mengukur kemampuan representasi matematis maka diperlukan indikator kemampuan representasi matematis. Menurut Suryana (2012:41) bentuk indikator kemampuan representasi yaitu: 1) Representasi visual: diagram, tabel, grafik atau gambar; 2) Persamaan atau ekspresi matematis; dan 3) Kata-kata atau teks tertulis.

Berdasarkan kurikulum yang berlaku segiempat merupakan materi yang masuk pada pokok bahasan geometri. Materi segiempat yang diajarkan kepada siswa kelas VII meliputi persegi panjang, layang-layang, belah ketupat trapesium dan jajar genjang. Menurut Muhassanah (2013:13) geometri merupakan salah satu bidang kajian dalam materi matematika sekolah yang memperoleh porsi yang besar yaitu sebesar $41 \%$ untuk dipelajari siswa SMP. Meskipun demikian, bukti-bukti di lapangan menunjukkan hasil belajar geometri masih rendah dan perlu ditingkatkan (Armadan dkk, 2017:50). Carrol (1998) menyatakan banyak siswa sekolah menengah tidak cukup memahami unsur-unsur geometri yang diperlukan untuk mendeskripsikan hubungan geometris. Kesalahan lain yang dialami siswa adalah mengenai persepsi visual. Mereka masih sulit memahami bahwa sifat suatu persegi tidak berubah bentuk dan ukurannya meskipun dilihat dari berbagai arah. Berkenaan dengan kesalahan maupun kesulitan siswa tentang konsep geometri, khususnya konsep segiempat dapat dimungkinkan bahwa siswa akan mengalami kesulitan dalam belajar matematika lebih lanjut. 
SMP RK Deli Murni Bandar Baru adalah salah satu sekolah di Sumatera Utara yang memiliki karakteristik yang hampir sama dengan sekolah yang ada di Indonesia pada umumnya, yaitu salah satunya telah menerapkan kurikulum 2013. Dari hasil observasi yang dilakukan diperoleh bahwa banyak siswa yang kesulitan mengerjakan soal matematika disebabkan oleh mereka tidak tahu harus memulai dari mana. Siswa mengalami kesulitan dalam menggambarkan kembali ataupun membuat simbol, model matematika dan kata-kata untuk menentukan langkah-langkah dalam menyelesaikan soal segiempat yang dibuat ke dalam soal cerita. Hal ini terkait dengan kemampuan representasi matematis siswa yang kurang karena siswa tidak mengerti apa langkah awal yang harus dituliskan dari soal cerita itu. Langkah awal dalam tahap pengerjaan soal-soal matematika adalah mengubah suatu objek dari dan ke bentuk verbal, simbol, tabel, atau grafik, sehingga proses pengubahan bentuk ini mengandung informasi yang dapat membantu menyelesaikan soal matematika. Untuk mengerjakan soal matematika, siswa dituntut supaya menuliskan informasi apa yang mereka ketahui dan apa yang diminta oleh soal untuk dikerjakan. Proses ini membutuhkan kemampuan representasi yang cukup.

Kesulitan siswa dalam geometri telah dijelaskan dengan penemuan penelitian pakar geometri dari Belanda yaitu Van Hiele, bahwa kesulitan dalam pembelajaran geometri berhubungan erat dengan perkembangan peringkat berpikir seseorang pada pengetahuan dan pemahaman tentang konsep geometri. Jika ditinjau dari proses belajar yang dilalui siswa, maka dapat dihubungkan dengan teori tentang tahap berpikir dalam belajar geometri yang dihasilkan berdasarkan penelitian Van Hiele. Teori belajar tersebut membahas tentang tingkatan-tingkatan yang dilalui dalam belajar geometri (Suherman dan Winataputra, 1993).

Menurut teori Van Hiele, seseorang akan melalui lima tahap perkembangan berpikir dalam belajar geometri. Kelima tahap perkembangan berpikir Van Hiele adalah level 0 (visualisasi), level 1 (analisis), level 2 (deduksi informal), level 3 (deduksi) dan level 4 (rigor). Hasil penelitian Herlambang (2013:75) menunjukkan bahwa kemampuan matematis siswa kelas VII ditinjau dari teori Van Hiele, siswa hanya mampu pada level 2 (deduksi informal) karena siswa mengalami kekurangan kosakata dalam mengungkapkan ide-ide yang dia miliki untuk menyelesaikan soal yang diberikan.

Melalui uraian di atas, untuk mengetahui kemampuan representasi matematis siswa pada materi geometri bangun segiempat, dapat digunakan Teori Van Hiele. Sehingga penelitian ini bertujuan untuk mengidentifikasi atau mendeskripsikan kemampuan representasi matematis siswa berdasarkan level teori Van Hiele pada materi segiempat.

\section{METODE}

Penelitian ini menggunakan metode deskriptif kualitatif karena bertujuan untuk mengidentifikasi atau mendeskripsikan kemampuan representasi matematis siswa berdasarkan teori belajar Van Hiele. Penelitian ini dilaksanakan di SMP RK Deli Murni Bandar Baru yang terletak di Jl. Jamin Ginting Km. 47 Bandar Baru, Kecamatan Sibolangit Kabupaten Deli Serdang, Sumatera Utara. Penelitian dilaksanakan pada bulan Mei 2021.

Subjek dalam penelitian ini adalah siswa kelas VII-Gentleness SMP RK Deli Murni Bandar Baru yang dipilih dengan teknik purposive sampling. Purposive sampling adalah pengambilan sumber data dengan pertimbangan tertentu. Penentuan 
subjek penelitian dilakukan dengan cara pemberian tes tingkat berpikir ditinjau dari Teori Van Hiele. Dipilih sebanyak 5 siswa yaitu masing-masing 1 siswa tiap tingkatan, antara lain 1 siswa kelompok level 0 (visualisasi), 1 siswa kelompok level 1 (analisis), 1 siswa kelompok level 2 (deduksi informal), 1 siswa kelompok level 3 (deduksi formal), dan 1 siswa kelompok level 4 (rigor). Sistem pengelompokan pencapaian tingkat berpikir geometri ini adalah dengan mengoreksi hasil pekerjaan siswa pada setiap tingkat. Pada tes VHGT, setiap level mempunyai lima pertanyaan. Siswa dikatakan mencapai level tertentu pada level Van Hiele apabila siswa tersebut mampu menjawab 3 dari 5 soal yang ada setiap level tertentu tersebut dengan benar.

Pengumpulan data dilakukan dengan memberikan tes dan wawancara. Tes pertama yaitu tes klasifikasi level Van Hiele yang bertujuan mengkategorikan siswa berdasarkan level Van Hiele. Tes kedua yaitu tes kemampuan representasi matematis yang bertujuan untuk melihat kemampuan representasi matematis siswa. Wawancara dilakukan dengan 4 siswa untuk mendapatkan hasil yang detail dan akurat.

Hasil tes klasifikasi level Van Hiele dianalisis secara deskriptif, begitu juga hasil wawancara dengan siswa dianalisis secara deskriptif. Sedangkan hasil tes kemampuan representasi matematis dianalisis secara kuantitatif.

Instrumen untuk tes kemampuan representasi matematis berbentuk uraian yang terdiri dari 3 soal materi segiempat, yang telah mempunyai validitas isi dan empiris. Untuk mengukur kemampuan representasi matematis, maka dilakukan penskoran pada hasil jawaban. Untuk menentukan kategori tingkat kemampuan representasi matematis siswa, maka skor kemampuan representasi matematis siswa dikonversikan ke bentuk kualitatif dengan memperhatikan pedoman pengkategorian pada tabel berikut.

Tabel 1. Kategori kemampuan representasi matematis

\begin{tabular}{cc}
\hline Nilai & Kategori \\
\hline $86-100$ & Sangat tinggi \\
$71-85$ & Tinggi \\
$56-70$ & Sedang \\
$0-55$ & Kurang \\
\hline
\end{tabular}

\section{HASIL DAN PEMBAHASAN}

Pemilihan subjek penelitian didasarkan pada kriteria-kriteria yang telah ditetapkan yaitu dengan pemberian soal tes tingkat berpikir geometri Van Hiele. Tes tingkat berpikir Van Hiele kepada siswa kelas VII-Gentleness SMP RK Deli Murni Bandar Baru. Hasil dari tes tingkat berpikir Van Hiele masing-masing siswa selanjutnya diperiksa dan diperoleh skor untuk masing-masing level/kategori. 


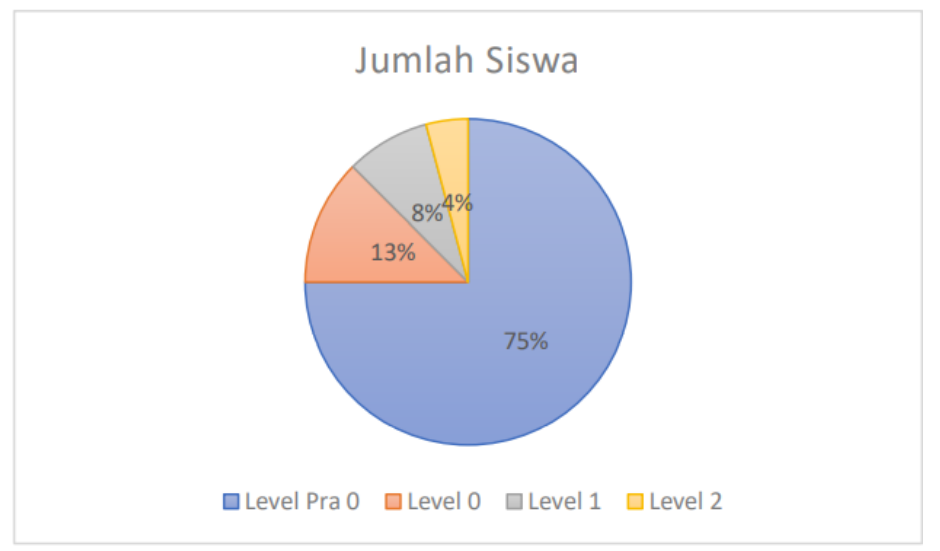

Gambar 1. Diagram jumlah siswa pada masing-masing level siswa berdasarkan Teori Van Hiele

Berdasarkan Gambar 1, dapat diketahui bahwa terdapat 13\% siswa berada pada level 0 (visualisasi), 8\% siswa berada pada level 1 (analisis), 4\% siswa berada pada level 2 (deduksi informal). Dari tes tersebut juga ditemukan sebanyak $75 \%$ siswa berada pada level previsualisasi yaitu siswa yang bahkan tidak dapat mencapai level 0 (visualisasi). Hal seperti apa yang ditemukan dalam penelitian Der-bang Wu dan Hsiulan Ma (Muarifah, 2016, p.69) bahwa $30 \%$ dari responden penelitian yang merupakan siswa Taiwan, belum mampu mencapai level terendah dari tingkatan berpikir Van Hiele. Sehingga Der-bang Wu memberi nama kelompok siswa ini kelompok tingkat "Below Level 0".

Berdasarkan hasil tes VHGT di atas, diambil 4 subjek secara acak, 1 siswa pada level previsualisasi yaitu subjek DP, 1 siswa pada level 0 (visualisasi) yaitu JS, 1 siswa pada level 1 (analisis) yaitu DWA, dan 1 siswa pada level 2 (deduksi informal) yaitu VVS.

Tabel 2. Daftar nama siswa kelas VII-Gentleness yang menjadi subjek

\begin{tabular}{ccc}
\hline No. & Kode siswa & Kategori Van Hiele \\
\hline 11 & DP & Previsualisasi \\
22 & JS & Visualisasi \\
33 & DWA & Analisis \\
44 & VVS & Deduksi informal \\
\hline
\end{tabular}

Analisis data pada penelitian ini diperoleh berdasarkan hasil tes kemampuan representasi matematis dan wawancara. Hasil wawancara tersebut digunakan sebagai penguat dan pendukung analisis data. Berdasarkan hasil tes kemampuan representasi matematis dan wawancara, pencapaian siswa terhadap indikator kemampuan representasi matematis disajikan pada tabel sebagai berikut: 
Tabel 3. Pencapaian indikator kemampuan representasi matematis siswa

\begin{tabular}{|c|c|c|c|c|c|}
\hline $\begin{array}{l}\text { Kemampuan } \\
\text { representasi } \\
\text { matematis }\end{array}$ & Indikator & DP & JS & DWA & VVS \\
\hline $\begin{array}{l}\text { Kemampuan } \\
\text { representasi visual }\end{array}$ & $\begin{array}{l}\text { Membuat gambar bangun dan } \\
\text { pola-pola geometri untuk } \\
\text { memperjelas masalah dan } \\
\text { memfasilitasi masalah }\end{array}$ & $\sqrt{ }$ & $\sqrt{ }$ & $\sqrt{ }$ & $\sqrt{ }$ \\
\hline \multirow[t]{2}{*}{$\begin{array}{l}\text { Kemampuan } \\
\text { representasi simbolik }\end{array}$} & $\begin{array}{l}\text { Membuat persamaan atau model } \\
\text { matematika dari representasi yang } \\
\text { lain }\end{array}$ & $\sqrt{ }$ & $x$ & $\sqrt{ }$ & $\sqrt{ }$ \\
\hline & $\begin{array}{l}\text { Menyelesaikan masalah dengan } \\
\text { melibatkan ekspresi matematis }\end{array}$ & $x$ & $x$ & $\sqrt{ }$ & $\sqrt{ }$ \\
\hline \multirow[t]{3}{*}{$\begin{array}{l}\text { Kemampuan } \\
\text { representasi verbal }\end{array}$} & $\begin{array}{l}\text { Menuliskan interpretasi dari suatu } \\
\text { representasi }\end{array}$ & $\sqrt{ }$ & $\sqrt{ }$ & $\sqrt{ }$ & $\sqrt{ }$ \\
\hline & $\begin{array}{l}\text { Menuliskan langkah-langkah } \\
\text { penyelesaian masalah dengan kata- } \\
\text { kata }\end{array}$ & $x$ & $x$ & $x$ & $\sqrt{ }$ \\
\hline & $\begin{array}{l}\text { Menjawab soal dengan } \\
\text { menggunakan kata-kata }\end{array}$ & $x$ & $\sqrt{ }$ & $\sqrt{ }$ & $\sqrt{ }$ \\
\hline
\end{tabular}

Berikut dijelaskan kemampuan representasi matematis pada masing-masing tingkat berpikir geometri.

\section{1) Kemampuan representasi matematis yang diperoleh subjek level previsualisasi}

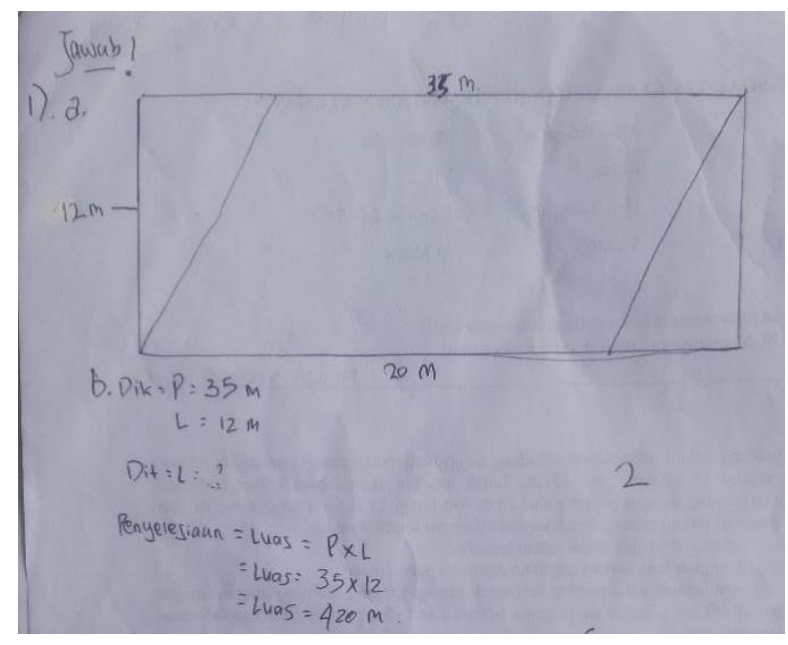

Gambar 2. Hasil pekerjaan tes kemampuan representasi matematis subjek DP

Berdasarkan hasil penelitian, subjek DP mengenal bangun segiempat dari bentuknya serta mampu menggambarkannya. Subjek mampu menentukan ukuran unsur bangun. Berdasarkan hasil wawancara subjek dapat menyebutkan ciri-ciri 
bangun persegi. Kemampuan representasi simbolik dan kemampuan representasi verbal masih lemah. Subjek DP hanya mampu membuat penyelesaian dengan mencari luas persegi panjang, namun masih belum dapat menyelesaikan masalah dengan sesuai. Subjek DP hanya mampu membuat interpretasi dari soal dan tidak mampu memenuhi indikator kemampuan representasi verbal yang lain.

\section{2) Kemampuan representasi matematis yang diperoleh subjek level visualisasi}

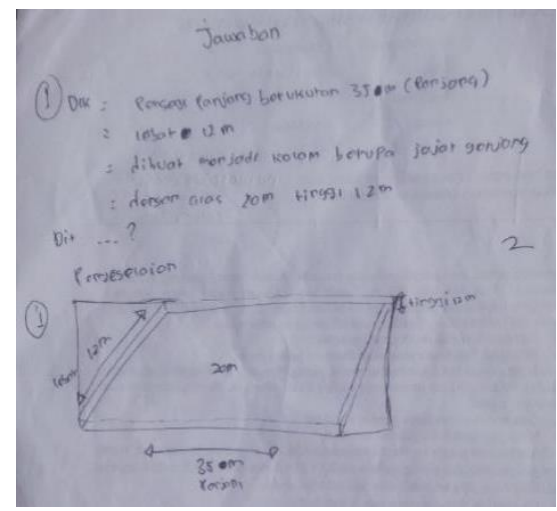

Gambar 3. Hasil pekerjaan tes kemampuan representasi matematis subjek JS

Hasil analisis kemampuan representasi matematis siswa level visualisasi (level 0) yaitu subjek JS memiliki kemampuan representasi visual, kemampuan representasi simbolik, dan kemampuan representasi verbal. Subjek JS mengenal bangun segiempat dari bentuknya serta mampu menggambarkannya. Subjek mampu menentukan ukuran unsur bangun. Berdasarkan hasil wawancara subjek dapat menyebutkan ciri-ciri bangun persegi. Kemampuan representasi simbolik dan kemampuan representasi verbal masih lemah. Terbukti saat mengerjakan soal subjek tidak mampu membuat penyelesaian dengan sistematis, dengan menggunakan rumus-rumus bangun segiempat dan perhitungan yang tepat.

\section{3) Kemampuan representasi matematis yang diperoleh subjek level analisis}

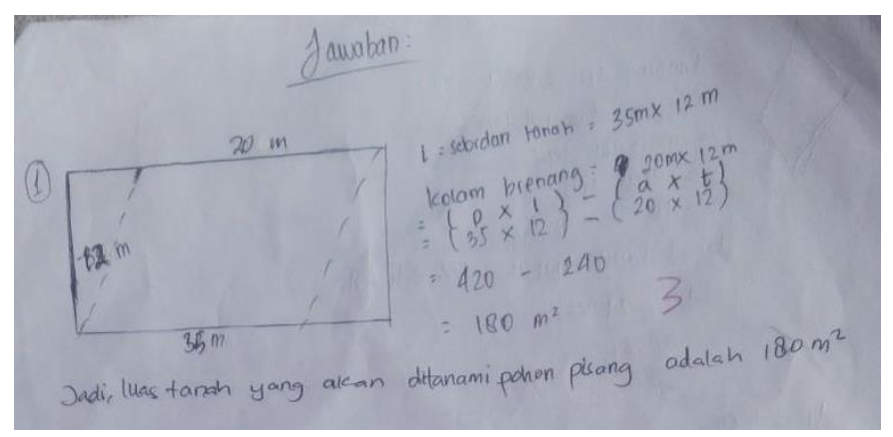

Gambar 4. Hasil pekerjaan tes kemampuan representasi matematis subjek DWA 
Hasil analisis kemampuan representasi matematis siswa level analisis (level 1) yaitu subjek DWA memiliki kemampuan representasi visual. Subjek DWA mengenal bangun segiempat dari bentuknya serta mampu menggambarkannya. Subjek mampu menentukan ukuran unsur bangun. Subjek DWA juga memiliki kemampuan representasi simbolik. Subjek dapat menyelesaikan soal dengan menggunakan persamaan-persamaan, dengan rumus-rumus dan penyelesaian yang tepat. Namun, subjek masih kurang dalam kemampuan representasi verbal. Dari 3 indikator kemampuan representasi verbal, 2 indikator yang terpenuhi dan 1 indikator tidak terpenuhi yaitu menuliskan langkah-langkah penyelesaian dengan kata-kata. Dalam merespon wawancara, subjek juga menjawab dengan sangat baik.

\section{4) Kemampuan representasi matematis yang diperoleh subjek level deduksi informal}

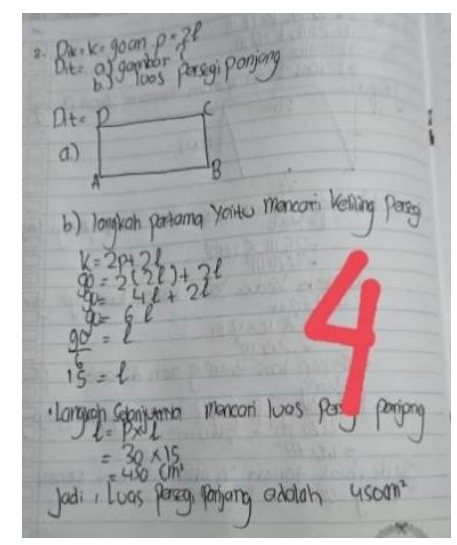

Gambar 5. Hasil pekerjaan tes kemampuan representasi matematis subjek VVS

Hasil analisis kemampuan representasi matematis siswa level deduksi informal (level 2) yaitu subjek VVS memiliki kemampuan representasi visual. Subjek VVS mengenal bangun segiempat dari bentuknya serta mampu menggambarkannya. Subjek mampu menentukan ukuran unsur bangun. Kemampuan representasi simbolik dan kemampuan representasi verbal juga sangat bagus. Terbukti saat mengerjakan soal subjek mampu menyelesaikan soal dengan baik dan benar. Subjek memahami bagaimana proses pengerjaan dan langkah-langkah penyelesaian yang tepat. Subjek juga mengerjakan soal dengan menggunakan rumus-rumus dan perhitungan yang tepat. Dalam menjawab pertanyaan ketika wawancara, subjek menjawab dengan mantap dan yakin. 
Berikut ini merupakan tabel yang memuat hasil akhir penilaian kemampuan representasi matematis siswa kelas VII-Gentleness SMP RK Deli Murni Bandar Baru.

Tabel 4. Hasil akhir penilaian kemampuan representasi matematis siswa

\begin{tabular}{ccccc}
\hline Level & Subjek & Total skor & Nilai akhir & Kategori \\
\hline Previsualisasi & DP & 4 & 33,33 & Kurang \\
Visualisasi & JS & 6 & 50 & Kurang \\
Analisis & DWA & 9 & 75 & Tinggi \\
Deduksi informal & VVS & 11 & 91.66 & Sangat tinggi \\
\hline
\end{tabular}

Berdasarkan tabel 4 di atas dapat dilihat bahwa:

1. Subjek DP dengan tingkat berpikir geometri previsualisasi (level pra 0) memiliki kemampuan representasi matematis kurang.

2. Subjek JS dengan tingkat berpikir geometri visualisasi (level 0) memiliki kemampuan representasi matematis kurang.

3. Subjek DWA dengan tingkat berpikir geometri analisis (level 1) memiliki kemampuan representasi matematis tinggi.

4. Subjek VVS dengan tingkat berpikir geometri deduksi informal (level 2) memiliki kemampuan representasi matematis sangat tinggi.

Penelitian tentang teori van Hiele di tingkat SMP ini pernah juga dilakukan oleh Desiningsih (2013). Desiningsih (2013) menemukan bahwa tingkat proses berpikir siswa berdasarkan teori Van Hiele adalah antara level 0 (visualisasi) dan tingkat transisi ke level 3 (deduksi). Dalam hal ini siswa yang berada pada tingkat transisi ke level 3 (deduksi) termasuk dalam kategori tinggi, sedangkan siswa yang termasuk dalam kategori sedang sudah mencapai transisi dari level 0 (visualisasi) menuju ke level 1 (analisis). Bedanya, penelitian Desiningsih tidak mengutamakan kemampuan representasi matematis saja, tetapi kemampuan matematika secara umum.

\section{SIMPULAN DAN SARAN}

Berdasarkan hasil dan pembahasan, dapat ditarik kesimpulan bahwa siswa yang dikategorikan menurut level Van Hiele mempunyai kemampuan representasi matematis yang berbeda-beda. Siswa level previsualisasi memiliki kemampuan representasi visual, namun memiliki kemampuan representasi simbolik dan kemampuan representasi verbal yang masih lemah. Siswa level visualisasi memiliki kemampuan representasi visual, memiliki kemampuan representasi verbal yang masih lemah dan tidak memiliki kemampuan representasi simbolik. Siswa level analisis memiliki kemampuan representasi visual dan kemampuan representasi simbolik, namun memiliki kemampuan representasi verbal yang masih lemah. Siswa level deduksi informal memiliki kemampuan representasi visual, kemampuan representasi simbolik dan kemampuan representasi verbal. 


\section{DAFTAR PUSTAKA}

Armadan, Somakim, dan Indaryanti. 2017. Kemampuan Representasi Matematis Siswa Pada Pembelajaran Berbasis Teori Van Hiele di Materi Segiempat Kelas VII SMP Negeri 1 Indralaya Utara. Jurnal Elemen, Vol. 3(1) : 49-57.

Carrol, W.M. 1998. Polygon Capture: A Geometry Game. Mathematics Teaching in Middle School, 4(2) : 90-94. Reston: NCTM.

Desiningsih, R., Syahbana, A., dan Kashardi. 2013. Proses Berpikir Siswa SMP dalam Belajar Geometri Berdasarkan Teori Van Hiele. AdmathEdu, Vol. 3(2) : $1-7$.

Herlambang. 2013. Analisis Kemampuan Pemecahan Masalah Matematika Siswa Kelas VII-A SMP Negeri 1 Kapahiang Ditinjau dari Teori Van Hiele. Tesis tidak diterbitkan. Bengkulu: Universitas Bengkulu.

Kemendikbud. 2015. Panduan Penilaian untuk Sekolah Menengah Pertama (SMP). Jakarta.

Muarifah, A. 2016. Analisis Keterampilan Geometri Siswa dalam Menyelesaikan Soal Geometri Segiempat Berdasarkan Tingkat Berpikir Van Hiele. Skripsi tidak diterbitkan. Semarang: Universitas Negeri Semarang.

Muhassanah, N. 2013. Analisis Keterampilan Geometri Siswa dalam Memecahkan Masalah Geometri Berdasarkan Tingkat Berpikir Van Hiele. Tesis tidak diterbitkan. Surakarta: Universitas Sebelas Maret.

Sapitri, I. dan Ramlah. 2019. Kemampuan Representasi Matematis dalam Menyelesaikan Soal Kubus dan Balok pada Siswa SMP. Prosiding Seminar Nasional Matematika dan Pendidikan Matematika SESIOMADIKA, Vol. 2(1C) : 829-835. ISSN : 2722-6379.

Suherman, E. dan Winataputra, U.S. 1993. Strategi Belajar Mengajar Matematika. Jakarta: Depdikbud.

Suryana, A. 2012. Kemampuan Berpikir Matematis Tingkat Lanjut (Advanced Mathematical Thinking) dalam Mata Kuliah Statistika Matematika 1. Makalah Pada Prosiding Seminar Nasional Matematika dan Pendidikan Matematika Jurusan Pendidikan Matematika FMIPA Universitas Negeri Yogyakarta, Yogyakarta, 10 November 2012. Hal: 37-48. ISBN : 978-979-16353-8-7.

Triono, A. 2017. Analisis Kemampuan Representasi Matematis Siswa Kelas VIII SMP Negeri 3 Tangerang Selatan. Skripsi tidak diterbitkan. Jakarta: Universitas Islam Negeri Syarif Hidayatullah. 